\title{
STEM-Based Computing Educational Resources on the Web
}

\author{
Tatiana Ringenberg \\ Purdue University \\ 401 Grant St. \\ KNOY 231 \\ West Lafayette, IN \\ tringenb@purdue.edu
}

\author{
Alejandra Magana \\ Purdue University \\ 401 Grant St. \\ KNOY 231 \\ West Lafayette, IN \\ admagana@purdue.edu
}

\begin{abstract}
This paper explores the scope of educational resources found on the web along with teaching and learning materials that can assist in integrating computational thinking into the classroom. Specifically, this paper focuses on finding and describing existing learning environments that integrate computational thinking into a STEM discipline. This survey provides initial steps towards the creation of a comprehensive list of STEM-based resources, on the web, which can help teachers to supplement and support their decision making when creating STEM curriculum.
\end{abstract}

\section{Keywords}

Computational thinking, STEM, learning resources, supplemental materials web-based educational materials.

\section{INTRODUCTION}

Computing is increasingly used to extend the capabilities and therefore findings of scientific research. For example, computing has enabled scientific breakthroughs by facilitating researchers through computerized instrumentation and detailed simulations to generate, visualize, and understand large amounts of scientific data. In tandem with the pervasive role of computing in science and engineering, there is a growing recognition of the importance of computational thinking.

Computational thinking [1] has been recognized as a collection of understandings and skills required for new generations of students who are proficient not only at using tools, but also at creating them and understanding the nature and implication of that creation [2].

For the scope of this study we refer to computational thinking as the combination of disciplinary knowledge (e.g., physics, biology, nanotechnology) [3] with thought processes (e.g., engineering thinking, quantitative reasoning, algorithmic thinking, systems thinking) involved in formulating problems and their solutions so that the solutions are represented in a form that can be effectively analyzed by an information-processing agent [4]. This requires using a set of concepts, such as

Permission to make digital or hard copies of all or part of this work for personal or classroom use is granted without fee provided that copies are not made or distributed for profit or commercial advantage and that copies bear this notice and the full citation on the first page. To copy otherwise, or republish, to post on servers or to redistribute to lists, requires prior specific permission and/or a fee. Copyright CJOCSE, a supported publication of the Shodor Education Foundation Inc. abstraction, recursion, and iteration, to process and analyze data, and to create real and virtual artifacts $[5,6]$.

\section{BACKGROUND}

Learning science, science education and cyberlearning research and funding have resulted in high-quality internet-based learning resources that can now be re-purposed to emphasize computational thinking. In conjunction, there has been an increase of teachers who use online resources for planning and executing their learning activities [7, 8]. While educational digital libraries exists, teachers frequently turn to the internet to find learning resources [9]. Though it is known that these teachers are searching for resources on the web, it is unclear what criteria they are using to choose resources for use in the classroom.

In a study focused on investigating educators' expectations and requirements for the design of educational digital collections for classroom use [10], the authors found that in addition to the quality of the resource, these users expected additional contextual information in the resource. Similarly, a different study that focused on a case study of how teachers find and use online resources [11], the authors identified that teachers interested in finding these resources were seeking on them characteristics such as age-appropriateness, accuracy and contemporariness [11].

This paper explores the landscape and characteristics of STEMbased computing educational resources found on the web together with teaching and learning materials that can facilitate the integration of computational thinking into the classroom. Specifically, this paper describes strategies and instructional media of existing learning environments that can integrate computational thinking into a STEM discipline together with lesson plans, activities and other curricula organized by specific grade levels. The guiding research question for this study is:

What are the characteristics of web based resources that fall under the definition or are identified as resources that can promote STEM-based computational thinking?

\section{Methods}

We followed the approach created by Bagiati and colleagues [12] to identify resources that can be described as promoting computational thinking in STEM disciplines. We started by identifying a list of resources mentioned on national reports and in portals that compile resources related to computational thinking. We then made a distinction among portals. Portals strictly created for research purposes were not included in this study. Portals with resources created by the same contributor were considered a single source and were only listed once within 
this study. Portals housing resources from different contributors and organizations were considered on a per-resource basis. Each website found within a portal was documented and noted as having been found in that particular portal. Any resource in the portal not pertaining to STEM was discarded from this study. Websites, within a given portal, which were found to be abandoned or for which the URL was found to no longer existing, were also discarded.

The next step was to identify additional resources on the web. These resources were found using a combination of the following search terms in Google: "computational thinking," "science," "technology," “engineering," "math," "STEM resources," "simulations," "lessons," "supplement," "K-12," "animations," and "teaching." Once all available resources through these searches were identified, we proceeded with their analysis. Our analysis started with identifying the primary instructional methods, instructional planning methods, scope of resources and evidence of research (e.g., publications, evaluations, feedback, testimonials or surveys) for each resource.

To identify the instructional method we identified whether the resources included simulations, games, programming environments, videos, images, animations, lectures, or books. We also noted whether instructional planning resources were available. Instructional planning resources are those supplemental materials consisting of motivation, orientation, information, application or evaluation activities [13]. Instructional planning resources were separated into lesson plans, tutorials, learning modules, activities, sample code, curriculum links, assignments and homework.

The procedure used in identifying the existence of research, instructional planning methods, instructional methods and program scope, consisted of applying the three click rule [14]. The three click rule refers to a heuristic applied to the design of the navigation for usable websites that argues that a user of a website should be able to find any information with no more than three mouse clicks [14]. Under this heuristic we assumed that users such as teachers may become frustrated if they cannot find the information within the three clicks, thus the name of "the three click rule." The complete search and analysis was performed for a second time to ensure accuracy and consistency.

\section{ANAlysis AND Results}

Results from this study identified 64 resources that were classified as STEM-based computational educational resources on the web, with 55 resources that can integrate computational thinking into K-12 classrooms to support learning in other STEM disciplines. Of the 55 resources, 31 were found to contain science materials, 22 contained technology materials, 14 contained engineering materials and 23 contained math materials.

As described earlier, the identified resources were then classified according to the primary instructional method. Table 1 depicts the number of resources found for each instructional method. Resources utilizing multiple instructional methods were also noted. These categories are described below.

Simulations refer to working representations of reality describing a model that may require some input parameters and then are executed by the learners. Programming environments refer to computing environments that embed a programming language mostly used for creating interactive stories and games.
Games refer to electronic and interactive media played by means of manipulating images.

Videos were defined as the reproduction of visual images. Illustrations refer to static pictures and drawings while animations refer to a sequence of images to create the illusion of movement. Lectures were defined as notes or presentations. Books refer to electronic compendium of written materials. For the purpose of this study, books were also defined to include resources with a significant amount of text.

TABLE I

TYPE OF INSTRUCTIONAL METHOD

\begin{tabular}{lc}
\hline \multicolumn{1}{c}{ Instructional Method } & Number of Resources \\
\hline Simulations & 25 \\
Videos & 13 \\
Games & 12 \\
Books & 10 \\
Animations & 9 \\
Illustrations & 9 \\
Programming environment & 8 \\
Lectures & 4 \\
\hline
\end{tabular}

As shown in Table 1, eight different types of instructional methods were identified.

We also identified whether each of the resources included any supplemental material that could serve as an instructional planning resource. As shown in Table 2, there were eight types of planning resources identified. Supplemental materials are used by educators as a blueprint or guidance to teach and incorporate the primary instructional tools.

Lesson plans refer to structured goal and objectives provided to teachers for a specific day's topic. Learning modules are organized collections of content that can range from a single lesson (i.e., a week-long activity with the goal of learning a single concept) to an entire curriculum (sets of week-long activities encompassing interrelated concepts, principles, procedures and problem-solving for a specific course or grade level). Learning modules often contain multiple instructional methods. In this case, a tool would be listed as a Learning Module as well as the other categories under which it would fall.

TABLE II

TYPE OF INSTRUCTIONAL PLANNING RESOURCE

\begin{tabular}{lc}
\multicolumn{2}{c}{ TYPE OF INSTRUCTIONAL PLANNING RESOURCE } \\
\hline Anstructional Method & Number of Resources \\
Activities & 26 \\
Lesson plans & 26 \\
Curriculum link & 23 \\
Learning modules & 17 \\
Tutorials & 14 \\
Sample code & 13 \\
Homework assignments & 8 \\
\hline
\end{tabular}

Tutorials refer to instructions, in text or video form, which provide a teacher with a guide on how to integrate a particular resource into the classroom or how to use a particular resource.

Activities refer to in-class interactions designed to teach students through doing. Activities are generally short term and cover a single concept. Sample code refers to code provided, by the resource or by site contributors, for a particular programing language. The goal of sample code is to teach by example. Curriculum links refer to ties made from the resource to a standard and accepted curriculum. Assessments refer to quizzes 
and tests that are used to gauge learners' progress to an extent. Assessments are generally monitored by the resource and results are provided to either the teacher or target audience. Homework assignments refer to work that is given outside of the classroom to reinforce concepts learned in the classroom.

TABLE III

RESOURCES BY GRADE LEVEL

\begin{tabular}{lc}
\hline Grade Level & Number of Resources \\
\hline Pre-K & 4 \\
K & 40 \\
1 & 40 \\
2 & 41 \\
3 & 43 \\
4 & 43 \\
5 & 44 \\
6 & 45 \\
7 & 44 \\
8 & 41 \\
9 & 48 \\
10 & 46 \\
11 & 44 \\
12 & 44 \\
College & 18 \\
All & 16 \\
Varies & 10 \\
Not available & 2 \\
\hline
\end{tabular}

Another measurement taken was the target audience for each resource. The target audience is defined as the student grade level for which a given resource was created. Table 3 shows the number of resources available for each grade level. Each number in the first column of the table represents its corresponding grade level. The category "K" lists number of resources found for kindergarten levels. The category " $\mathrm{C}$ " represents resources targeted for college level students. The category " $\mathrm{A}$ " represents resources that are created for all ages and not for a specific grade level. "NA" category refers to resources that did not have grade level information available. The "V" category is for resources whose grade levels depend on the sub-resources.

Figure 1 shows the resources found to be used by audiences at multiple grade levels.

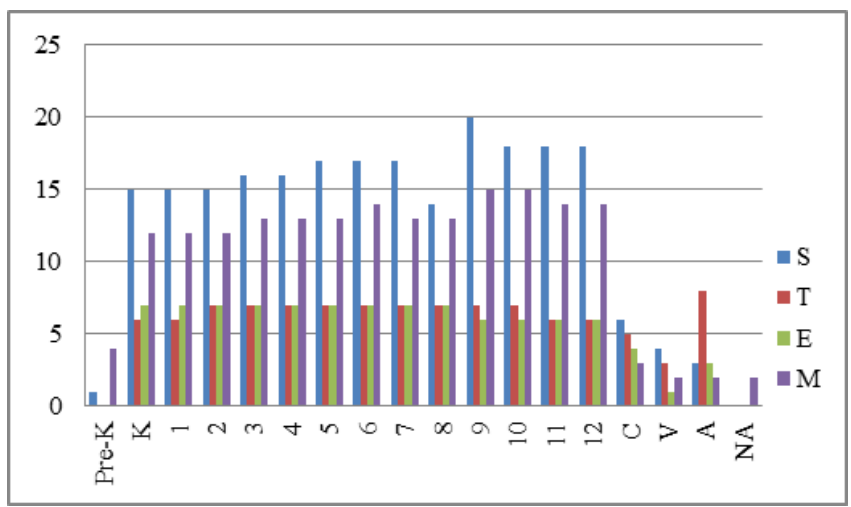

Figure 1. Frequency of STEM resources by grade level

Additionally we conducted searches aiming to identify available evidence of research or evaluation for each of the resources. Evidence of research is defined as some form of proof that the resource is effective or has been tested in some way. Table IV below divides these resources into publications, testimonials, evaluations, surveys and feedback.
TABLE IV

TYPES OF EVIDENCE OF RESEARCH

\begin{tabular}{lc}
\hline \multicolumn{1}{c}{ Instructional Method } & Number of Resources \\
\hline Publications & 21 \\
Feedback & 5 \\
Testimonials & 4 \\
Evaluations & 3 \\
Surveys & 2 \\
\end{tabular}

Publications provide formal evidence of the efficacy of a resource. Publications take the form of journals, conference papers, books and articles. Testimonials are responses from users provided by the resource. Evaluations are feedback in the form of pre-established criteria. Evaluations can be done by teachers, users or outside sources. Surveys are informal feedback in the form of multiple-choice questions asked to users about the product. Feedback is defined as reactions or concerns of users to a particular resource. There is either an email address provided for which feedback can be given or there is a specific link for feedback.

Our criteria in the analysis were that all forms of resource evidence must be available on the resource website or linked to the resource website. For instance, if a resource has no publications but provides an HTML link to a website that has used its resource for publications; the resource receives credit for publications. Resources that contained multiple forms of evidence were listed under each type of evidence under which they fell. Approximately 31 of the total of resources had no visible evidence of research or evaluation at all.

The last analysis concerned resource scope. Short resources were defined as those resources which were meant to be done within a single sitting. This means that, if used in class, it would take at most an hour or two of class time. Moderate resources are those resources which take more than a single class period, but no more than a week. Long resources are those resources that take an extended amount of time. They often include an entire curriculum. It was found that 44 resources included short resources, 22 included moderate and 16 included long.

Appendix A lists all resources identified through in this paper as well as all of the associated statistics as previously discussed.

\section{Discussion}

This descriptive study provides an in depth view of (a) available web-based STEM computational resources, (b) primary tools used to teach STEM and (c) supplemental instructional tools that can be used by teachers to integrate the primary instructional tools. From the graphs and statistics listed in this paper, some trends can be suggested.

As an observational note, independent STEM resources are very difficult to find. Though there are several resource portals, many of them have either the same information or outdated and abandoned resources. Resources not indexed in portals were difficult to find and had to be encountered through the right combination of search terms. This led to an abundance of unusable resources to be discarded. Central, up to date, resource hubs are needed to make finding computational thinking resources easier for teachers.

Results from Figure 1 suggest that web resources are available, fairly consistently from K-12 grade levels. It is worth noting that there was a spike in resources for the 9-10 grade levels. Some resources specifically targeted for these grade levels were found particularly in math. 
Educational resources for Pre-K, College, all ages and a varying audience are shown to be lacking. A potential explanation for this trend may be due to the broad nature of the age appropriateness of resources for each of the audiences. K-12 audiences have more focused curriculums with very specific standards that are more easily followed by resources. Audiences such as college professors and students, however, contain too many sub-audiences with varying curricula. Another possible explanation for the lack of resources outside of the K-12 audiences is the breadth of STEM disciplines outside of these.

From highest to lowest, the instances of STEM resources were as follows: science (31), math (23), technology (22) and engineering (14).

We expected the greatest quantity of resources to occur in science. This is due to the broadness of the topic. It is worth noting that most science resources were focused on individual areas of science. For instance, BioQuest is an excellent example focusing largely on biological sciences.

Upon first examination of technology and math, it appears that they are nearly on par. However, when broken down by grade level, it is evident that more math resources were available to each grade than technology resources. Around 30\% of resources at each grade level, within K-12, were math resources whereas only about $17 \%$ were technology resources. This shows that, although there are several technology resources at our disposal, not many of them cover the full spectrum for $\mathrm{K}-12$ audiences.

The lack of engineering resources is not unexpected. Engineering is a more advanced discipline that largely isn't taught in K-12. Engineering is also a difficult category to define without the use of science, technology and math.

Most of the resources found combine multiple branches of STEM. For instance, out of the 14 engineering resources found in this study, only 4 had solely engineering resources. It is believed that this is largely due to (a) the ambiguity of the understanding of the term engineering and lack of preeminence of traditional stipulated standards at the K-12 level and (b) the multidisciplinary nature and reliance of engineering on science, technology and math.

There are 38 more occurrences of supplementary resources than there are of the primary tools. Further analysis shows that simulations are the only significant source of primary instructional tools. Though there is an abundance of simulations at 25 total occurrences, the other primary instructional tools are somewhat lacking. In the future, we will look further into the other primary instructional tools to understand this gap. It is possible that this gap exists due to the nature of STEM.

Even though simulations were the most prevalent primary resources, they were the least explained. There were hardly any tutorials or guides on how to use the simulations. Many of these simulations were not intuitive. This leaves teachers or even learners often guessing its functionality.

Learning objectives were removed from the scope of this study due to our inability to easily find them. Very few resources had learning objectives listed. Most of the objectives that were found were based on the resource as a whole, not the individual units within each resource. There were few sites that listed the objectives based on each learning unit; however, these were not enough to be examined in this study. Learning objectives was not the only category that was removed from the findings.

\section{CONCLUSION AND IMPLICATIONS}

Research studies have reported that searching and verifying online learning resources poses a challenge to teachers already pressed for time [15]. As a result of this investigation we concur that independent STEM-based computational resources are very difficult to find. Though there are several resource portals, many of them have either the same information or outdated and abandoned resources. Resources not indexed in portals are difficult to find and had to be encountered through the right combination of search terms. This led to an abundance of unusable resources that had to be discarded.

Similarly, over half $(31 / 55)$ of the total usable resources did not provide at least one of the categories used in this paper. This suggests that (a) STEM web resources may not be user friendly or (b) STEM resources are not well supported. All of the information that could be found within three clicks was added to this paper. Anything beyond three clicks was not included because it may exceed most users' tolerance for searching. This observation goes hand-in-hand with the lack of instructions for simulations. If resources are to be effective they must be well explained and must contain all necessary information within a reasonable number of clicks.

Research has also identified that many educators limit their information seeking primarily within search engines and do not take full advantage of educational-related digital libraries specifically designed and crated for specific teaching and learning needs [15]. While digital libraries can solve the problem of finding these resources, there is still the issue of additional characteristics users are looking for in each of them. As more and more of these resources move to digital libraries, instructional designers and educational researchers should keep in mind that educators are not only looking for a collection of resources, but also additional well-documented contextual information (e.g., age-appropriateness) and evidence of their high quality as well (e.g., accuracy and scientific evidence). This study provides initial steps towards that goal by providing a list of STEM-based computational resources on the web that includes useful additional information, which can help teachers and parents make decisions and eventually integrate these resources easily for educational purposes.

\section{REFERENCES}

[1] Wing, J.M., Computational thinking. Communications of the ACM, 2006. 49(2): p. 33-35.

[2] Soh, L.K., et al., Renaissance computing: an initiative for promoting student participation in computing. 2009.

[3] [NRC], Report of a workshop on the pedagogical aspects of computational thinking, in National Research Council. 2011, National Research Council of the National Academies: Washington, D.C.

[4] Cuny, J., L. Snyder, and J.M. Wing, Demystifying Computational Thinking for Non-Computer Scientists. Work in progress, 2010.

[5] [CSTA]. Operational definition of computational thinking. Computer Science Teacher Association 2012 [cited 2012 March 15]; Available from: .

[6] Barr, V. and C. Stephenson, Bringing computational thinking to K-12: what is Involved and what is the 
role of the computer science education community? ACM Inroads, 2011. 2(1): p. 48-54.

[7] Hedtke, R., et al., Service industry for teachers? Using the Internet to plan lessons. European journal of education, 2001. 36(2): p. 189-193.

[8] Recker, M., Perspectives on Teachers as Digital Library Users: Consumers, Contributors, and Designers. D-Lib Magazine, 2006. 12(9): p. 2.

[9] Williams, T., Teachers' Link to Electronic Resources in the Media Center: A Local Study of Awareness, Knowledge and Influence. 2004.

[10] Sumner, T., et al. Understanding educator perceptions of "quality" in Digital Libraries. in Proceedings of Joint Conference of Digital Libraries 2003. New York, NY: IEEE.

[11] Recker, M.M., J. Dorward, and L.M. Nelson, Discovery and use of online learning resources: Case study findings. Journal of Educational Technology and Society, 2004. 7: p. 93-104.

[12] Bagiati, A., et al., Engineering Curricula in Early Education: Describing the Landscape of Open
Resources. Early Childhood Research \& Practice, 2010. 12(2).

[13] Newby, T., et al., Instructional technology for teaching and learning: Designing instruction, integrating computers, and using media. Educational Technology \& Society, 2000. 3: p. 2.

[14] Porter, J., Testing the three-click rule. User Interface Engineering, 2003.

[15] Perrault, A.M., An Exploratory Study of Biology Teachers' Online Information Seeking Practices. School Library Media Research, 2007. 10.

\section{AUThOR INFORMATION}

Tatiana Ringenberg, Undergraduate Student of Computer and Information Technology at Purdue University, tringenb@purdue.edu

Alejandra J. Magana, Ph.D. Assistant Professor of Computer and Information Technology at Purdue University, admagana@purdue.edu

\section{Appendix:}

\begin{tabular}{|c|c|c|c|c|c|c|c|}
\hline Resource Name & Website (URL) & $\begin{array}{l}\text { Grade } \\
\text { Level }\end{array}$ & $\begin{array}{l}\text { STEM } \\
\text { field }\end{array}$ & $\begin{array}{l}\text { Instructional } \\
\text { Planning } \\
\text { Resource }\end{array}$ & $\begin{array}{l}\text { Instructional } \\
\text { Method }\end{array}$ & $\begin{array}{l}\text { Evidence } \\
\text { Of } \\
\text { Research }\end{array}$ & $\begin{array}{l}\text { Length of } \\
\text { Resource }\end{array}$ \\
\hline CyberChase & http://pbskids.org/cyberchase & $\begin{array}{l}\text { Pre-K- } \\
12\end{array}$ & M & A & $G, V$ & $\mathrm{P}, \mathrm{E}$ & Short \\
\hline eNLVM & $\begin{array}{l}\text { http://enlvm.usu.edu/ma/nav } \\
\text { bb_school.jsp?sid=emready\& } \\
\text { coid=all }\end{array}$ & $\begin{array}{l}\text { Pre-K- } \\
12 \\
\end{array}$ & M & LP, LM, A & & & Short \\
\hline Teacher Vision & $\begin{array}{l}\underline{\mathrm{http}: / / \text { www.teachervision.fen. }} \\
\underline{\text { com/ }}\end{array}$ & $\begin{array}{l}\text { Pre-K- } \\
12\end{array}$ & SM & $\mathrm{LP}, \mathrm{A}, \mathrm{AS}$ & B, I, G, V & & $\begin{array}{l}\text { Short - } \\
\text { Moderate }\end{array}$ \\
\hline eGFI & http://teachers.egfi-k12.org/ & $\mathrm{K}-12$ & $\mathrm{E}$ & LP, A & & & Short \\
\hline iCoachMath.com & $\begin{array}{l}\text { http://www.icoachmath.com/ } \\
\text { static/AboutUs.aspx }\end{array}$ & $\mathrm{K}-12$ & M & $\mathrm{CL}, \mathrm{AS}, \mathrm{T}$ & & & Short \\
\hline Let's Go Learn & http://letsgolearn.com/ & $\mathrm{K}-12$ & M & AS, A, CL, LM & $\mathrm{V}, \mathrm{G}$ & & $\begin{array}{l}\text { Short - } \\
\text { Moderate } \\
\end{array}$ \\
\hline Mathalicious & $\underline{\mathrm{http}: / / \text { www.mathalicious.com }}$ & K-12 & M & LP, CL, LM & $\mathrm{V}, \mathrm{I}, \mathrm{B}$ & SU & $\begin{array}{l}\text { Short - } \\
\text { Moderate }\end{array}$ \\
\hline BrainPop & http://www.brainpop.com & K-12 & S & LP, LM, T, A, CL & $\mathrm{G}, \mathrm{V}, \mathrm{A}$ & $\mathrm{P}$ & Short \\
\hline Froguts & http://www.froguts.com/ & K-12 & S & LM, AS & $S$ & $\mathrm{P}$ & Short \\
\hline $\begin{array}{l}\text { HHMI's } \\
\text { BioInteractive }\end{array}$ & $\begin{array}{l}\underline{h t t p: / / w w w . h h m i . o r g / b i o i n t e ~} \\
\text { ractive/stemcells/animations. } \\
\text { html }\end{array}$ & K-12 & $\mathrm{s}$ & LP, LM, A & $S, V, L, A$ & & Short \\
\hline illumin & http://illumin.usc.edu/ & K-12 & S & LP & I, B & & $\begin{array}{l}\text { Moderate - } \\
\text { Long }\end{array}$ \\
\hline $\begin{array}{l}\text { United States } \\
\text { Department of } \\
\text { Agriculture: } \\
\text { Agriculture in the } \\
\text { Classroom } \\
\end{array}$ & http://www.agclassroom.org/ & K-12 & $\mathrm{s}$ & LP, LM, A & $S, G, V$ & & $\begin{array}{l}\text { Short - } \\
\text { Moderate }\end{array}$ \\
\hline $\begin{array}{l}\text { Engineering Is } \\
\text { Elementary }\end{array}$ & $\begin{array}{l}\text { http://www.mos.org/eie/20_u } \\
\text { nit.php }\end{array}$ & $\mathrm{K}-12$ & STEM & LP ,LM, CL, AS & & $P, E$ & Short \\
\hline
\end{tabular}




\begin{tabular}{|c|c|c|c|c|c|c|c|}
\hline Resource Name & Website (URL) & $\begin{array}{l}\text { Grade } \\
\text { Level }\end{array}$ & $\begin{array}{l}\text { STEM } \\
\text { field }\end{array}$ & $\begin{array}{c}\text { Instructional } \\
\text { Planning } \\
\text { Resource } \\
\end{array}$ & $\begin{array}{l}\text { Instructional } \\
\text { Method }\end{array}$ & $\begin{array}{l}\text { Evidence } \\
\text { Of } \\
\text { Research }\end{array}$ & $\begin{array}{c}\text { Length } \\
\text { of } \\
\text { Resource } \\
\end{array}$ \\
\hline $\begin{array}{l}\text { Engineering } \\
\text { Pathway }\end{array}$ & $\frac{\underline{\text { http://www.engineeringpath }}}{\frac{\text { way.com/ep/k12/k12_curricu }}{\text { lar_res.jhtml;jsessionid=KOMD }}}$ & $\mathrm{K}-12$ & STEM & & & $\begin{array}{l}\text { NOT } \\
\text { APPLICAB } \\
\text { LE }\end{array}$ & \\
\hline Lesson Planet & $\begin{array}{c}\mathrm{http}: / / \text { www.lessonplanet.com } \\
\text { /lesson-plans/science }\end{array}$ & $\mathrm{K}-12$ & STEM & LP, LM, A, CL & & $\mathrm{F}, \mathrm{A}$ & $\begin{array}{l}\text { Short - } \\
\text { Moderate }\end{array}$ \\
\hline $\begin{array}{c}\text { NASA's Simulation- } \\
\text { Based Aerospace } \\
\text { Engineering } \\
\text { Teacher } \\
\text { Professional } \\
\text { Development } \\
\text { Program } \\
\end{array}$ & $\frac{\text { https://simaero.rti.org/pages/ }}{\text { Coursework.aspx }}$ & $\mathrm{K}-12$ & STEM & & & NA & \\
\hline Teach Engineering & $\begin{array}{l}\frac{\text { http://www.teachengineering. }}{\text { org/ }}\end{array}$ & $\mathrm{K}-12$ & STEM & LP, A, AS & I & $\mathrm{P}$ & $\begin{array}{l}\text { Short - } \\
\text { Moderate }\end{array}$ \\
\hline teachers' domain & $\begin{array}{l}\frac{\mathrm{http}: / / \text { www.teachersdomain.o }}{\mathrm{rg} / \text { browse/?fq_hierarchy=k12. }} \\
\text { sci.engin } \\
\end{array}$ & $\mathrm{K}-12$ & STEM & CL, LM, A, LP & $\mathrm{V}, \mathrm{I}$ & & Short \\
\hline Know It All & $\frac{\underline{\text { http://www.knowitall.org/nas }}}{\underline{\text { a/ksnn/index.html }}}$ & $\mathrm{K}-12$ & STM & LM, A & S, I & $\mathrm{F}$ & Short \\
\hline $\begin{array}{l}\text { Intel Computer } \\
\text { Clubhouse } \\
\text { Network }\end{array}$ & $\frac{\text { http://www.computerclubhou }}{\text { se.org/ }}$ & $\mathrm{K}-12$ & $\mathrm{~T}$ & $\begin{array}{l}\text { In Person } \\
\text { Instruction }\end{array}$ & $\mathrm{PE}$ & NA & \\
\hline $\begin{array}{c}\text { Concord } \\
\text { Consortium }\end{array}$ & http://www.concord.org/ & $\begin{array}{c}\text { K-12, } \\
\text { College }\end{array}$ & $\mathrm{S}$ & A, LM & S & $\mathrm{P}, \mathrm{A}$ & Short \\
\hline $\mathrm{PhET}$ & $\begin{array}{l}\text { http://phet.colorado.edu/en/s } \\
\text { imulations/category/by-level }\end{array}$ & $\begin{array}{c}\text { K-12, } \\
\text { College }\end{array}$ & SM & A, AS, HW & $\mathrm{S}, \mathrm{A}, \mathrm{L}$ & $\mathrm{P}$ & Short \\
\hline ROBOLAB @ CEEO & $\frac{\mathrm{http}: / / \text { www.ceeo.tufts.edu/ro }}{\text { bolabatceeo/ }}$ & $\begin{array}{c}\text { K-12, } \\
\text { College }\end{array}$ & $\mathrm{TE}$ & $\begin{array}{l}\text { LP, T, A, SC, CL, } \\
\text { LM }\end{array}$ & PE & A & $\begin{array}{l}\text { Short - } \\
\text { Long }\end{array}$ \\
\hline $\begin{array}{c}\text { Computer Science } \\
\text { Teachers } \\
\text { Association } \\
\end{array}$ & http://csta.acm.org/ & $\begin{array}{l}\text { K-12, } \\
\text { college, } \\
\text { industry }\end{array}$ & $\mathrm{T}$ & & & $\mathrm{P}$ & $\begin{array}{c}\text { Full } \\
\text { Curriculu } \\
\text { m }\end{array}$ \\
\hline Women@ @CS & http://women.cs.cmu.edu/ & $\begin{array}{c}\text { K-12, } \\
\text { Women }\end{array}$ & $\mathrm{T}$ & CL & $\mathrm{I}$ & & \\
\hline Kid's Field Day & $\begin{array}{c}\text { http://www.ksre.ksu.edu/fiel } \\
\text { dday/kids/ }\end{array}$ & $\mathrm{K}-5$ & $\mathrm{~S}$ & LM & I, S & & Short \\
\hline Mad Dog Math & $\frac{\text { http://www.maddogmath.com }}{\text { /about.html }}$ & $\mathrm{K}-6$ & M & A,AS, LM & & $\mathrm{E}$ & $\begin{array}{l}\text { Short - } \\
\text { Long }\end{array}$ \\
\hline $\begin{array}{c}\text { The K-8 } \\
\text { Aeronautics } \\
\text { Internet Textbook } \\
\end{array}$ & http://wings.avkids.com/ & $\mathrm{K}-8$ & SE & LP, A & I & & Short \\
\hline Explore Leanring & www.explorelearning.com & $3-12$ & SM & $\mathrm{LP}, \mathrm{CL}$ & $S, G$ & $\mathrm{P}$ & Short \\
\hline Scratch & scratch.mit.edu & $3-12$ & $\mathrm{~T}$ & $\mathrm{~T}$ & $S, P E, V$ & $P$ & Moderate \\
\hline $\begin{array}{l}\text { Computer Science } \\
\text { in a Box }\end{array}$ & $\frac{\text { http://www.ncwit.org/unplug }}{\text { ged }}$ & $5-9$ & $\mathrm{~T}$ & & & & $\begin{array}{c}\text { Full } \\
\text { Curriculu } \\
\mathrm{m}\end{array}$ \\
\hline WISE & http://wise.berkeley.edu/ & $5-12$ & $\mathrm{~S}$ & LP, LM, T, AS & $\mathrm{S}, \mathrm{A}$ & $\mathrm{P}, \mathrm{A}$ & $\begin{array}{l}\text { Short - } \\
\text { Moderate }\end{array}$ \\
\hline EcoScience Works & $\begin{array}{c}\underline{\text { www.fbr.org/swksweb/esw.ht }} \\
\underline{\mathrm{ml}}\end{array}$ & $6-8$ & S & LP, AS, A, CL, LM & S & $\mathrm{P}$ & Long \\
\hline Engineer Your Life & $\begin{array}{c}\text { http://www.engineeryourlife. } \\
\text { org/ }\end{array}$ & $\begin{array}{r}6-8, \\
\text { Girls }\end{array}$ & $\mathrm{E}$ & & V & & \\
\hline $\begin{array}{l}\text { sciencecourseware } \\
\text {.org }\end{array}$ & $\frac{\text { http://nemo.sciencecoursewa }}{\text { re.org/ }}$ & $\begin{array}{l}\text { 6-12, } \\
\text { college }\end{array}$ & S & AS,T, CL, LM & $\mathrm{S}, \mathrm{V}$ & $\mathrm{T}, \mathrm{A}$ & Short \\
\hline Stock Trak & http://www.stocktrak.com/ & $6-12$ & SM & & $\mathrm{S}$ & & Long \\
\hline $\begin{array}{l}\text { Mathematics for } \\
\text { the Digital Age and } \\
\text { Programming in } \\
\text { Python }\end{array}$ & $\frac{\text { http://www.skylit.com/matha }}{\text { ndpython.html }}$ & $\begin{array}{l}\text { 9-12, } \\
\text { college }\end{array}$ & M & & B & & Long \\
\hline
\end{tabular}




\begin{tabular}{|c|c|c|c|c|c|c|c|}
\hline Resource Name & Website (URL) & $\begin{array}{l}\text { Grade } \\
\text { Level }\end{array}$ & $\begin{array}{l}\text { STEM } \\
\text { field }\end{array}$ & $\begin{array}{c}\text { Instructional } \\
\text { Planning } \\
\text { Resource } \\
\end{array}$ & $\begin{array}{l}\text { Instructional } \\
\text { Method }\end{array}$ & $\begin{array}{l}\text { Evidence } \\
\text { Of } \\
\text { Research } \\
\end{array}$ & $\begin{array}{c}\text { Length } \\
\text { Of } \\
\text { Resource } \\
\end{array}$ \\
\hline $\begin{array}{l}\text { DNA Learning } \\
\text { Center }\end{array}$ & http://www.dnalc.org/about/ & $\begin{array}{l}9-12 \\
\text { college }\end{array}$ & S & A & S, A & AR & $\begin{array}{l}\text { Short - } \\
\text { Long }\end{array}$ \\
\hline $\begin{array}{l}\text { Math Open } \\
\text { Reference }\end{array}$ & $\frac{\text { http://www.mathopenref.com }}{\text { /index.html }}$ & 10 & M & AS, LM & I, B & $\mathrm{T}$ & Short \\
\hline EDICS & $\frac{\text { http://ocw.mit.edu/ans7870/ }}{\text { resources/edics/index.htm }}$ & College & $\mathrm{E}$ & & $S, A, L, B$ & & Long \\
\hline $\begin{array}{l}\text { Statistics and } \\
\text { Visualization for } \\
\text { Data Analysis and } \\
\text { Inference }\end{array}$ & $\begin{array}{c}\frac{\text { http://ocw.mit.edu/resources }}{\text { /res-9-0002-statistics-and- }} \\
\begin{array}{c}\text { visualization-for-data- } \\
\text { analysis-and-inference- }\end{array} \\
\text { january-iap-2009/ }\end{array}$ & College & $\mathrm{TE}$ & & $\mathrm{L}$ & $\mathrm{F}$ & Long \\
\hline MathWorks & $\begin{array}{l}\underline{\text { http://www.mathworks.com/ }} \\
\text { company/events/webinars/w } \\
\text { bnr56249.html?id=56249\&p1 } \\
=869881405 \& \mathrm{p} 2=869881423\end{array}$ & College & EM & $\mathrm{T}$ & $\mathrm{V}, \mathrm{S}, \mathrm{PE}$ & $P$ & $\begin{array}{l}\text { Short - } \\
\text { Moderate }\end{array}$ \\
\hline $\begin{array}{l}\text { Evolution of } \\
\text { Physical } \\
\text { Oceanography }\end{array}$ & $\begin{array}{c}\frac{\text { http://ocw.mit.edu/resources }}{\text { /res-12-000-evolution-of- }} \\
\text { physical-oceanography- } \\
\text { spring-2007/ }\end{array}$ & College & $S$ & & B & & Long \\
\hline Agripedia & $\frac{\text { http://oir.fod.msu.edu/OIR/Bi }}{\text { oAg/bioag_gen.asp }}$ & College & SE & CL & & & \\
\hline $\begin{array}{l}\text { DDA Medical } \\
\text { Simulations }\end{array}$ & $\begin{array}{c}\frac{\mathrm{http}: / / \text { www.zeroonezero.com }}{\text { Lmedical/simulations/training }} \\
\text { - } \text {-simulations/medical- } \\
\text { technology-simulation.html } \\
\end{array}$ & College & ST & A & S, A & $\mathrm{P}$ & NA \\
\hline Open Sees & $\frac{\text { http://opensees.berkeley.edu/ }}{\text { OpenSees/home/about.php }}$ & College & STEM & SC & $S, P E$ & & Short \\
\hline $\begin{array}{l}\text { Quizzes with a } \\
\text { THEME }\end{array}$ & $\begin{array}{l}\frac{\text { http://csta.acm.org/Resources }}{\text { /sub/ResourceFiles/BruceMax }} \\
\text { wellThemeQuizzes.pdf }\end{array}$ & College & $\mathrm{T}$ & SC, AS & PE & & Short \\
\hline TryEngineering & $\frac{\text { http://www.tryengineering.or }}{\mathrm{g} /}$ & A & $\mathrm{E}$ & LP, CL & G & SU & $\begin{array}{l}\text { Short - } \\
\text { Moderate }\end{array}$ \\
\hline $\begin{array}{c}\text { Topology and } \\
\text { Geometry Software }\end{array}$ & $\frac{\text { http://www.geometrygames.o }}{\mathrm{rg} /}$ & A & M & $\mathrm{T}$ & G & & Short \\
\hline $\begin{array}{c}\text { Discovery: } \\
\text { Dinosaur Central }\end{array}$ & $\begin{array}{l}\text { http://dsc.discovery.com/dino } \\
\underline{\text { saurs/dinosaur- }} \\
\text { games/dinosaur- } \\
\text { viewer/dinosaur-viewer.html }\end{array}$ & A & $S$ & LM & $\mathrm{S}, \mathrm{A}, \mathrm{G}$ & & Short \\
\hline $\begin{array}{l}\text { Nobel Prize: All } \\
\text { Educational } \\
\text { Productions } \\
\end{array}$ & $\frac{\frac{\text { http://www.nobelprize.org/e }}{\text { ducational/all_productions.ht }}}{\underline{\text { ml }}}$ & A & $S$ & LP, LM & G & & Short \\
\hline $\begin{array}{l}\text { Google: Exploring } \\
\text { Computational } \\
\text { Thinking: Lessons } \\
\text { and Examples } \\
\end{array}$ & $\begin{array}{c}\text { http://www.google.com/edu/ } \\
\begin{array}{c}\text { computational- } \\
\text { thinking/lessons.html }\end{array}\end{array}$ & A & STEM & $\mathrm{LP}, \mathrm{SC}, \mathrm{A}, \mathrm{CL}$ & & & $\begin{array}{l}\text { Short - } \\
\text { Moderate }\end{array}$ \\
\hline Alice & http://www.alice.org/ & A & $\mathrm{T}$ & $\begin{array}{l}\text { T, LP, A, SC, CL, } \\
\text { LM }\end{array}$ & S, PE, B & $\mathrm{P}, \mathrm{T}$ & $\begin{array}{l}\text { Short - } \\
\text { Long }\end{array}$ \\
\hline $\begin{array}{c}\text { Beginner } \\
\text { Developer } \\
\text { Learning Center }\end{array}$ & $\frac{\text { http://msdn.microsoft.com/en }}{\underline{\text { us/beginner/default.aspx }}}$ & A & $\mathrm{T}$ & $\mathrm{SC}, \mathrm{T}$ & $\mathrm{V}, \mathrm{B}$ & & Short \\
\hline $\begin{array}{l}\text { Computational } \\
\text { Fairy Tales }\end{array}$ & $\begin{array}{c}\frac{\text { http: } / / \text { computationaltales.blo }}{\text { gspot.com } / \mathrm{p} / \text { posts-by- }} \\
\text { topic.html }\end{array}$ & A & $\mathrm{T}$ & & B & $\mathrm{F}$ & Short \\
\hline $\begin{array}{l}\text { Computer Science } \\
\text { Unplugged }\end{array}$ & http://csunplugged.com/ & A & $\mathrm{T}$ & $\mathrm{A}, \mathrm{CL}$ & $\mathrm{V}$ & $\mathrm{P}$ & Long \\
\hline Furby Autopsy & $\frac{\text { http://www.phobe.com/furby }}{L}$ & A & $\mathrm{T}$ & $\mathrm{T}, \mathrm{A}$ & & & Moderate \\
\hline Phrogram & $\frac{\text { http://phrogram.com/content }}{\text { /about.aspx }}$ & A & $\mathrm{T}$ & $\mathrm{SC}, \mathrm{LP}, \mathrm{T}$ & S, PE & $\mathrm{T}$ & $\begin{array}{l}\text { Short - } \\
\text { Long }\end{array}$ \\
\hline $\begin{array}{l}\text { GameMaker (by } \\
\text { YoYo Games) }\end{array}$ & http://www.yoyogames.com/ & A & $\mathrm{TE}$ & $\mathrm{T}, \mathrm{A}, \mathrm{SC}$ & $S, P E, G$ & & Short-Long \\
\hline
\end{tabular}




\begin{tabular}{|c|c|c|c|c|c|c|c|}
\hline Resource Name & Website (URL) & $\begin{array}{l}\text { Grade } \\
\text { Level }\end{array}$ & $\begin{array}{l}\text { STEM } \\
\text { field }\end{array}$ & $\begin{array}{c}\text { Instructional } \\
\text { Planning } \\
\text { Resource } \\
\end{array}$ & $\begin{array}{l}\text { Instructional } \\
\text { Method }\end{array}$ & $\begin{array}{l}\text { Evidence } \\
\text { Of } \\
\text { Research } \\
\end{array}$ & $\begin{array}{c}\text { Length } \\
\text { Of } \\
\text { Resource } \\
\end{array}$ \\
\hline NCWIT & $\begin{array}{c}\underline{\text { http://www.ncwit.org/work.p }} \\
\text { ractices.html }\end{array}$ & $\begin{array}{c}\text { A, } \\
\text { Women }\end{array}$ & $\mathrm{T}$ & & & & \\
\hline BioQuest & http://bioquest.org/ & V & S & A, LM, CL & S & $\mathrm{P}$ & $\begin{array}{c}\text { Short - } \\
\text { Moderate }\end{array}$ \\
\hline $\begin{array}{c}\text { Molecular } \\
\text { Workbench }\end{array}$ & $\frac{\text { http://mw.concord.org/model }}{\text { er/ }}$ & V & ST & LM & S, A & & $\begin{array}{l}\text { Short - } \\
\text { Long }\end{array}$ \\
\hline $\begin{array}{l}\text { Discovery } \\
\text { Education }\end{array}$ & $\frac{\underline{\mathrm{http}: / / \text { stem.discoveryeducatio }}}{\underline{\text { n.com/ }}}$ & V & STEM & LP, CL, LM & $\mathrm{V}, \mathrm{G}$ & & $\begin{array}{l}\text { Short - } \\
\text { Long }\end{array}$ \\
\hline Interactivate & $\frac{\text { http://www.shodor.org/intera }}{\text { ctivate/activities/ }}$ & V & STM & LM, AS & $S$ & $\mathrm{~F}$ & Short \\
\hline
\end{tabular}

Grade Level: A=All; V=Varies NA=Not Available

Instructional Planning Resource: $\mathrm{LP}=$ Lesson Plans; T=Tutorials; $\mathrm{A}=$ Activities; $\mathrm{SC}=$ Sample Code; $\mathrm{CL}=\mathrm{Curriculum} \mathrm{Link;} \mathrm{AS}=\mathrm{Assessments;}$

HW=Homework Assignments; LM=Learning Module

Instructional Method: S=Simulation; PE=Programming Environment; G=Games; V=Videos; I=Illustrations/Pictures; A=Animations; L=Lectures;

$\mathrm{B}=$ Books

Evidence of Research: $\mathrm{P}=$ Publications (Journals and Papers); $\mathrm{A}=$ Articles (magazines and online); $\mathrm{T}=$ Testimonials; $\mathrm{SU}=\mathrm{Surveys}$; F=Feedback; NA=Not Available; $\mathrm{AR}=$ Annual Reports; $\mathrm{E}=$ Evaluations 